\title{
Exploring Relationship Between Tqm and Software Productivity
}

Exploración de la relación entre TQM y la productividad del software

\section{Exploração da relação entre Gestão da Qualidade Total (TQM) e Produtividade de Software}

\section{Kapil Jaiswal ${ }^{1}$ \\ Minakshi Garg²}

Received: May 15 $15^{\text {th }}, 2019$

Accepted: July $25^{\text {th }}, 2019$

Available: September 16 ${ }^{\text {th }}, 2019$

How to cite this article:

K. Jaiswal and M. Garg, "Exploring Relationship Between Tqm and Software

Productivity," Revista Ingeniería Solidaria, vol. 15, no. 3, 2019. doi: https://doi.org/10.16925/2357-6014.2019.03.09

Artículo de investigación. https://doi.org/10.16925/2357-6014.2019.03.09

1 University School of Business, Chandigarh University, Mohali, Punjab ORCID: https://orcid.org/0000-0003-3701-3895

E-mail: Kapil.Jaiswal@oati.net

2 University School of Business, Chandigarh University, Mohali, Punjab

ORCID: https://orcid.org/0000-0003-0877-4337 


\section{Abstract}

Introduction: This publication is the product of research, carried out in the field of management in year 201819 , which supports the work of a PhD in Business Management at Chandigarh University. The purpose of this research is to explore the relation between Total Quality Management (TQM) constructs and productivity in the IT industry. This study has been conducted for organizations operating in the Tricity (Chandigarh, Panchkula and Mohali) and NCR (Noida, Gurgaon and Delhi) regions.

Problem: The control of rising operational costs in any organization has become a challenge and is a major aspect in the sustainability of an organization. Implementation of TQM may reduce these costs by improving productivity in the software development process.

Objective: The objective of the research is to explore if there any relationship exists between TQM and productivity in software development organization and whether TQM positively impacts productivity.

Methodology: The study is based on a descriptive research design. A total of 206 respondents were selected using convenient sampling while 90 responded back on the survey. Exploratory factor Analysis and Multiple Linear Regression techniques were applied to obtain the results.

Results: Out of 4 elements of TQM considered in this study, Customer Focus and Continuous improvement were found to be positively related to productivity while Total Management Commitment was found to not be related to productivity. The hypothesis related to People Management was abandoned because it was highly correlated to other TQM elements.

Conclusion: TQM positively impacts productivity in software development organizations.

Originality: This study tried to create a causal mathematical model between TQM variables and productivity.

Limitations: Sample size and TQM elements were limited based on availability of time and resources.

Keywords: TQM, Software Productivity, Total Management Commitment, Customer focus, Continuous improvement, People Management, Factor Analysis.

\section{Resumen}

Introducción: este artículo es producto de una investigación realizada en el campo de la gestión en el año 2018-2019, que respalda el trabajo de un doctorado en gestión empresarial en la Universidad de Chandigarh. El propósito de esta investigación es explorar la relación entre las construcciones de Gestión de Calidad Total (TQM) y la productividad en la industria de TI. Este estudio se realizó para organizaciones que operan en las regiones de Tricity (Chandigarh, Panchkula y Mohali) y NCR (Noida, Gurgaon y Delhi).

Problema: el control del aumento de los costos operativos en cualquier organización se ha convertido en un desafío y es un aspecto importante en la sostenibilidad de una organización. La implementación de TQM puede reducir estos costos al mejorar la productividad en el proceso de desarrollo de software.

Objetivo: el objetivo de la investigación es explorar si existe alguna relación entre TQM y la productividad en la organización de desarrollo de software y si TQM impacta positivamente en la productividad.

Metodología: el estudio se basa en un diseño de investigación descriptivo. Un total de 206 encuestados fueron seleccionados mediante un muestreo conveniente, mientras que 90 respondieron a la encuesta. Se aplicaron técnicas de análisis factorial exploratorio y de regresión lineal múltiple para obtener los resultados.

Resultados: de los cuatro elementos de TQM considerados en este estudio, se encontró que el enfoque al cliente y la mejora continua están relacionados positivamente con la productividad, mientras que el compromiso total de gestión no está relacionado con la productividad. La hipótesis relacionada con la gestión de personas se abandonó porque estaba altamente correlacionada con otros elementos TQM.

Conclusión: TQM impacta positivamente la productividad en las organizaciones de desarrollo de software. 
Originalidad: este estudio trató de crear un modelo matemático causal entre las variables TQM y la productividad.

Limitaciones: el tamaño de la muestra y los elementos TQM se limitaron en función de la disponibilidad de tiempo y recursos.

Palabras clave: TQM, productividad de software, compromiso total de gestión, enfoque al cliente, mejora continua, gestión de personas, análisis factorial.

\section{Resumo}

Introdução: esta publicação é produto da pesquisa realizada no campo de gestão em 2018 e 2019, que corrobora o trabalho de um doutorando em Gestão Empresarial na Chandigarh University. 0 propósito desta pesquisa é explorar a relação entre as construções de Gestão da Qualidade Total (TQM, na sigla em inglês) e produtividade na indústria de TI. Este estudo foi conduzido para organizações que operam nas regiões de Tricity (Chandigarh, Panchkula e Mohali) e no Território da Capital Nacional (Noida, Gurgaon e Delhi).

Problema: o controle dos custos operacionais crescentes em qualquer organização se tornou um desafios e é um aspecto importante na sustentabilidade de uma organização. A implementação de TQM pode reduzir esses custos ao melhorar a produtividade no processo de desenvolvimento de software.

Objetivo: o objetivo da pesquisa é explorar se há alguma relação entre TOM e produtividade em organizações de desenvolvimento de software e se a TQM impacta positivamente a produtividade.

Metodologia: o estudo está baseado em um desenho de pesquisa descritivo. Um total de 206 participantes foram selecionados a partir de uma amostragem conveniente e 90 deles responderam à pesquisa. Técnicas exploratórias de análise fatorial e regressão linear múltipla foram aplicadas para obter os resultados.

Resultados: dos quatro elementos de TQM considerados neste estudo, Foco no Cliente e Melhoria Contínua se mostraram positivamente relacionados à produtividade, enquanto Comprometimento Total de Gestão não se mostrou relacionado à produtividade. A hipótese relacionada ao Gerenciamento de Pessoas foi descartada porque estava estreitamente correlacionada a outros elementos de TQM.

Conclusão: a TQM impacta positivamente a produtividade em organizações de desenvolvimento de softwares.

Originalidade: este estudo buscou criar um modelo matemático causal entre as variáveis de TQM e a produtividade.

Limitações: o tamanho da amostra e os elementos de TQM eram limitados com base na disponibilidade de tempo e de recursos.

Palavras-chave: TQM, Software de Produtividade, Comprometimento Total de Gestão, Foco no Cliente, Melhoria Contínua, Gerenciamento de Pessoas, análise fatorial.

\section{INTRODUCTION}

\subsection{IT Industry}

The IT industry achieved a major breakthrough in the 1990s and is now one of the important industries of India. The main reason for the quick development of the software industry is its huge reservoir of technically skilled human resources, which has led India to be transformed into a software superpower. 
Despite challenges, such as the continued technology slowdown in the global market, strong fundamentals and core value position of the software and services industry led to outperforming all other sectors in the country.

Most of the corporations among Fortune 500 and Global 2000 lists are sourcing IT-ITES from India. Indian IT companies have set up over 600 delivery centers across the world and are engaged in providing services in over 200 cities across 78 countries. In terms of the national GDP, the sector revenues have grown from 1.2 per cent in FY1997-98 to nearly 9.3 per cent in FY2015-16. India continues to maintain leadership position in the global sourcing arena, accounting for almost 56 percent of the global sourcing market size in 2016 as compared to 52 percent in 2012 [1].

\subsection{Total Quality Management (TQM)}

An organization should put quality at the top of its strategy to compete effectively and fit efficiently into the global market. Quality is an important parameter in products and services that help keep customers satisfied.

TQM has no single, specific theoretical formation, according to Akbar and Awan [2]. According to Deming [3], TQM is a group of activities in the organization that involve everyone in the company i.e. managers and workers working together to make a systemic and integrated effort, geared towards improving performance at every productivity level. Kanji and Asher [4] define TQM as a continuous improvement process for an organization, groups of people or individuals.

According to studies, TQM provides better and improved business practices that result in a reduction in costs, increased productivity and quality enhancement which lead to customer satisfaction.

Operationally, TQM is defined as everyone's involvement across entire functions in an organization where they are stimulated and trained in a bid to continuously improve the quality of the product or service process. It is done using statistical quality control methods to satisfy the customer and benefit all members of an organization in a given society.

\subsection{Productivity}

Productivity, in simple terms, is defined as the ratio of output to input. Hence, it is subtly assumed that both output and input can be measured, just like any other commodity.

The common understanding about the size of a Software project is that it is directly related to the effort required to execute the project. Commonly used software 
productivity measurement methods include FP, SLOC, System Meter, Magnitude and Use Case Point [5].

Productivity can be evaluated with a range of different dimensions based on perspective. While the FP analysis caters to productivity measurement for the customer dimension, effort required is more appropriate for the developer's dimension and cost is more relevant for the management dimension.

A couple of approaches, measuring lines of code and function points, have been put forward for measuring software productivity; both have their own pros and cons. Productivity in software is also impacted by a lot of factors like the complexity of software, the language and tools used, the skill of the project team, communication between team members and clients, clarity of functional and non-functional requirements etc. Many of these depend upon the culture (focus) and size (capacity) of the organization and yet not all of them can be objectively measured.

Just like many variables in management science, measuring productivity is not an easy task. The only way to measure productivity is through indirect means that involve measuring other variables; then from the result found, productivity is calculated [6].

This study will analyze the relationship between the level of implementation of TQM constructs in an organization and the level of productivity in related practices and processes. The scope is limited to the function of software development for the whole organization and does not include any other department like HR, Operations etc.

In several studies, it is evident that TQM leads to improved business practices that result in reduced costs, increased productivity and enhancement of quality, hence providing customer satisfaction.

Many studies have been performed analyzing software productivity. Software productivity is dependent upon many parameters, some of which are the programming language, hardware configuration, tools used, development model, processes followed etc. This study tries to find out the relation between productivity improvement processes and TQM related processes used in the software development function of the organization.

Basically, this study tries to ascertain, how an organization fair on some of the factors that affect productivity (as mentioned in the previous paragraph) with respect to levels of TQM implementation. These factors or parameters, which may indirectly evaluate or indicate productivity and TQM levels have been derived after a thorough literature review. 
The current paper fills the gap by analyzing the relationship between TQM and productivity in service, especially in the IT (Software Development) sector in the NCR (National Capital Region) and Tricity (Chandigarh, Mohali and Panchkula) regions. Accurate productivity measurement has been one of the elusive techniques and so, most of the time, the level of productivity in Software Development is indicative in nature. This study can provide another way to indicate the level of productivity by relating the same with TQM processes.

\section{LITERATURE REVIEW}

\subsection{TQM}

Kassicieh et al. [7] studied the impact of TQM training and evaluated the performance benefits of successful TQM implementation.

Rahman and Bullock [8] studied the existing relationship between practices of TQM and the performance of the organization. Their study used 261 Australian manufacturing companies' data. They created a TQM model with 10 elements: commitment of the workforce, personal training, use of teams, shared vision, customer focus, computer-based technologies, cooperative supplier relations, technology utilization, just-in-time principles, and the enablers of continuous improvement. The soft elements of TQM were the first six elements while the hard elements of TQM were the last four elements.

Most studies consider organizational characteristics as the only variable in relationship moderation between organizational characteristics and TQM practices [9]. According to Terziovski and Samson [10], there were notable differences in how organizational performance and TQM relate when the organization size is considered, specifically affecting the development of a new product. Larger companies were likely to reap more TQM benefits than smaller companies.

TQM is an idea of management or a methodology consisting of practices, principles and techniques [11]. According to them, most quality frameworks were common in three principles; customer focus, teamwork and continuous improvement. Through established practices, every principle applies which are in turn reinforced by a wide set of techniques.

Haar and Spell [12], in their study, concluded that companies that have a higher independent workplace level, application of performance standards, use of group problems, and application of teams, had a higher likelihood of adopting TQM. This was more common in larger companies than in smaller ones. 
In the study done by Brah, Tee \& Rao [13] they concluded that two factors, the size of the company and the adoption of TQM, have a significant correlation with quality management implementation and a higher quality performance level. The analysis shows that the implemented TQM program length (or duration) has effects on quality performance.

Oluwatoyin and Oluseun [14], in their research undertaken in Nigeria, have proven an organization needs to employ TQM for them to remain competitive. The finding also revealed more effort geared toward service delivery; improvement adds customer value since the organization focuses more on customer satisfaction. Additionally, employees get empowered through teamwork and training, which drive the organization's continuous improvement $(\mathrm{Cl})$.

The study done in Spain by Corredor and Goñi [15], examined TQM's impact on the performance of an organization. The study further examined the effects of an industry implementing TQM at an early or late stage. It concluded that TQM has no significant influence on the performance of the organization.

An empirical study carried out in Vietnam by Hoanga et al. [16] attempted to establish if there are any differences in TQM implementation among companies concerning ownership, the degree of innovation and type of industry. They concluded that firms with higher levels of innovation have higher TQM implementation rates as compared to companies with less innovation.

\subsection{Software productivity}

The definition of a product's lifecycle productivity is the KLOC ratio to total life-cycle costs [17]. In this study, the model used includes the size of the software, usage of automated tools, the capability of the personnel, etc. as variables in measuring productivity. According to the findings in the study, improving quality leads to and increase in both development and maintenance productivity [17].

Productivity is simply the ratio of actual output to input over a period of time. Inputs include resources being modified or processed (such as materials, equipment, Customers and staff) and the outputs are services and goods [18], [19].

Productivity is difficult to deal with for three main reasons. First, the outputs and the inputs are expressed in different forms. Physical terms measure output, for instance, tonnes, value, units or kilowatts. However, the inputs have a physical difference and include measures of people - e.g. skills, numbers, cost, hours worked - or materials - e.g. cost and tonnes - Second, the ratio provides little information about performance by itself. A ratio of 0.8 ratio is very small unless we can compare with 
previous time periods, the production productivity potential of the operation or some form of benchmark. Third, we can use many different ratios.

Authors like Sasser et al.,[20]; Witt and Witt, [21], Jones, [22]; Jones and Lockwood, [23]; have pointed out that characteristics and features of services are what limits productivity management and measurement.

Premraj, et al, [24] stated that measuring productivity is not easy due to its primary definition; the ratio of outputs to inputs requires an objective measurement method for both commodities. Unfortunately, this cannot take place since the notion of output for software is not direct. Problems arise with the lines of code because of layout, language difference and because most software engineering activities do not involve code directly. Function Points (FP) and their many variants are an alternative that are in quite widespread use despite various criticisms. Secondly, there are a large number of factors that impact productivity, most of which that are inherently difficult to access. They include the difficulty of the task, the skill of the project team, ease of customer/client interaction and the nonfunctional requirement levels imposed, like performance and dependability. Third, many of these factors have clear interactions between them, for example, if the quality is disregarded, it will be easier to be productive [24].

The topic of software productivity has generated considerable interest over the years. This comes from our different vantage points. First, to consider different ways of measuring productivity. Second, to facilitate effort prediction - see for example Jeffery and Low [25] who uses productivity to build simple effort prediction tools -. Third, as a form of benchmarking, such as making international comparisons analyzing productivity and software development practices across four regions (India, Japan, USA and Europe).

The primary input that drives functionality delivered in a software project is the software development labor. The input-output ratio is used to measure software development productivity: productivity= SIZE OF APPLICATION DEVELOPED / LABOR CONSUMED DURING DEVELOPMENT[26].

\section{Productivity:Productivity $=\frac{\text { Size Of Application Developed }}{\text { Labour Consumed During Development }}$}

The size of output from software development is measured in two popular ways which have emerged over the years. One of the ways is SLOC (counting source line for code) [27], [22]. The second one is carrying out the analysis of function points [25], [28], [29], [30]. According to Banker, et al. [31] there are many project factors that influence 
software development productivity that have been investigated in previous research. Project management practices, staff experience, the programming language used, the type of application, and the stability of the development platform and user requirements (project size or function points) are the relevant ones [26].

Petersen, K. [32], quoted that "you cannot predict nor control what you cannot measure". A portion of the numerous variables that seem to impact programming productivity are: human resource factors such as experience and team size; process factors such as programming language and tools; product factors such as complexity, software type and programming language; and computer factors such as storage and timing constraints [33]. The mix and communication of all of these variables make the estimation, measurement, examination and tracking of productivity rates exceptionally troublesome [34]. Boehm [35] employed a model to analyze the effect of differences in firm, category, environment, language, country, team size, system size and project duration, together with seven COCOMO factors. The seven COCOMO factors incorporate reliability of the required software, the fundamental storage constraint, experience of programming language, execution time limitation, virtual machine essentialness, utilization of software tools and use of modem programming practices on process productivity and lines-of-code productivity [36]. The software development industry has highly variable productivity rates [34].

An IBM study by Walston and Felix [37], found 29 factors that were fundamentally correlated with productivity. Bailey and Basili [38] identified 21 productivity parameters, in an analysis of data from the NASA/Goddard Space Flight Center. Vosburgh et al. [39], found that there are about 14 fundamental productivity variables, with practical usage of modem programming and computer size development explaining $24 \%$ of the variation in productivity, according to the ITT findings [37].

In Boehm's COCOMO model [35], 15 software programming factors were found which had significant impact on productivity. However, major factors such as application type and programming language were excluded in these models.

Aron [40], found that, differences in system difficulty, described by the number of associations with other system components, and project duration, resulted in variation of productivity for a group of IBM projects involving systems programs and business applications. Kitchenham [41] discovered that productivity differed with the working environment and programming language level. Findings by various researchers also concluded that productivity varies with experience of the programmer, hardware constraints, size of the team, size of the project, duration and modem programming practices etc. [35], [42], [39], [31], [43]. 
Maxwell and Forselius [44], in their paper, considered the following factors that affect productivity in software development and indicate the process followed. However, the factors do not include all variables (the language used, database, input and outputs of software, etc.) which could actually be used to measure productivity. The factors are: customer participation, staff availability, tools and standards reuse, requirements volatility [44].

Trendowicz and Munch [45] made an entire investigation of elements that affect productivity through a methodical literature review and industrial experiences made up of industrial projects, surveys and workshops. They classify diverse variables into groups such as human resources, product, project and process factors. They also investigated their reported frequency in four contexts: project data repositories, productivity measurement, cost modeling and studies on software process improvement.

The variables most often cited include the programming language, domain and development type. Also, impact variables are those incorporated in the model to explain the variability of context factors. In this case, some of the most influential factors include: team capability and experience, complexity of software, project constraints and usage of tools. According to the authors, the human side of the development process is the most essential one followed by tools and techniques and, contrary to instinct and conviction, reuse is definitely not a key factor in efficiency [45].

A company may be using its resources efficiently by following process specifications. However, it may not be using them efficiently if it does not produce what the customer wants. Khan [46], in his study, proves the hypothesis that the operating income of organizations can be improved by TQM efforts. This is made evident by the fact that firms that have employed effective TQM, outweigh other firms in the control group. TQM efforts result in an increase in sales [46].

Blackburn et al [47], in their paper, considered the following aspects of judging productivity levels through a questionnaire.

1. Use of prototyping: to show how the proposed software intends to work.

2. Better initial customer specifications.

3. CASE tools Arid technology use.

4. Agreeing on development stages or modules.

5. Minimum rework or recoding.

6. Improvement of the project team.

7. Better strategies for testing.

8. Code or modules reuse. 
9. Changes in modulation or linkages (Testing of smaller modules and standard interface speed coding with parallel development).

10. Better software engineers or programmers.

This research shows that the difference lies in people and process: there is no way of escaping a software crisis through automatic means. The productivity and paradoxes show that the management of effort and time in software development can have powerful impacts on time, productivity and cost [47].

Several researchers (e.g. Giarini, [48]; Grönroos, [49]) have argued that quality and productivity cannot be dealt with separately in the case of services. In practice, the development of a single measure of service productivity is likely to prove a tough challenge. On the other hand, this does not undermine our approach to conceptualize service productivity, because there seems to be opportunities to resort to proxy measures in the operationalization efforts [48]. The same approach is being followed in this study as well.

Anselmo and Ledgard [50], asserted that there are no acceptable productivity benchmarks for a software environment. Comparisons are generally based upon literature advocating a given method. The study considered the following factors which impact upon or provide indication of software productivity levels in an organization.

- Ability to deal with complexity.

- Reusability.

- Quality.

The following properties of a software being developed that have been known to affect the man-hours and time to develop and support a software product.

- Independence.

- Flexibility.

\subsection{TQM, performance, efficiency or productivity}

Many studies (Abusa[51], Bani Ismail[52], Gharakhani, et al, [53]) have taken operational or financial performance or efficiency as an indication of productivity and used terms like efficiency and productivity in conjunction with each other. Implementation of TQM has been considered an important factor for enhancing organizational productivity and efficiency [53]. 
Samson and Terziovski [10], in their study, examined the relationship between TQM practices and operational performance for manufacturing companies in Australia and New Zealand. This study concluded that some TQM practices of leadership, management of people and customer focus could significantly predict the operational performance. [10]

Jaafreh and Al-Abedallat [54], in their study, highlighted the positive impact of TQM practices on productivity and performance of organization. This study measured organizational performance in terms of customer satisfaction and found that focus on quality improves customer and employee satisfaction, efficiency and profitability. The following TQM practices were found tp be significantly related to operational performance;: Leadership, strategic planning, customer focus, and employee relations [54].

Prajogo and Sohal, [55], in their findings concluded that TQM has the strongest relationship with quality performance. Also, TQM is more effective for pursuing differentiation in terms of quality rather than innovation [55].

TQM is defined as a complete philosophy of management whose aim is to improve every organizational function continuously. TQM achieves this aim by making use of the total concept of quality from the initial acquisition of resources up to the point of sale to the customer [56].

Reduction of variance in the process should result in increased uniformity in the output, as well the reduction of rework and waste [57], [58] because problems related to quality are identified and fixed, immediately [59]. Flynn et al. [60] found that active process management leads to an improved percent-passed ultimate inspection with almost zero rework [59].

Process management is another core TQM practice that is directly and positively related to quality performance. This result confirms the findings in studies [59], [60], [58] that investigated the relation of process management to quality performance [59].

As many of these findings differ, there is scope for additional research, catering to productivity in the Indian IT context and analyzing if the process, focused through TQM, produces any impact.

Variables to indicate productivity levels in this study refer to the COCOMO factors via. Required software reliability, Execution Time constraint, Main storage constraint, Virtual Machine Volatility, Programing language experience, Use of modern programming practices, Use of Software tools and other factors based on the literature reviewed. 


\section{MATERIALS AND METHODS}

\subsection{TQM elements}

The following elements or soft aspects of TQM are considered: Total Management Commitment (TMC), People Management (PM), Customer Focus (CF) and Continuous Improvement $(\mathrm{CI})$, keeping in mind to limit the scope of this paper. These elements have been derived from the literature reviewed.

\subsection{Research Objectives, Questions and Hypotheses Formulation}

To explore if there is any significant relationship between the TQM implementation levels and productivity of the software development process of an organization.

The following 4 hypotheses were formed based on the above objective.

1. Ho: TMC does not have any significant impact on productivity.

2. Ho: PM does not have any significant impact on productivity.

3. Ho: CF does not have any significant impact on productivity.

4. Ho: Cl does not have any significant impact on productivity.

\subsection{Research Design and Instrument Construction}

This paper uses a descriptive cross-sectional study design. It follows a similar methodology to the Total Quality Management performed by Talib et al.,[62] ; Kumar et al.,[63]; Salaheldin,[64]. The primary data for this study was collected through a questionnaire circulated through email.

The design of the questionnaire was based on earlier similar studies [14], [65], [51]. The survey consisted of a set of multiple-choice questions. The possible answers varied from favourable to unfavourable statements with an equal number of choices for both options (favourable/unfavourable). Respondents were asked to select one from five choices; strongly agree, agree, not sure, disagree, or strongly disagree. The explicit responses to the survey questions are consolidated so that responses with the more favorable attitudes will have the higher scores while responses with the least favourable (or unfavourable) attitudes will have the lowest scores.

Demographic information was collected through the initial section of the survey. The second section collected information regarding the TQM elements and their levels as well as productivity. The target respondents to this survey were mostly Technical 
leads/Project managers - middle management - whose fundamental role is to manage and maintain quality of deliverables. Another type of respondent belonged to QA departments of organizations. Responsibility for this role is to ensure that a project follows defined processes and meets minimum quality standards.

\subsection{Sample Size and Sampling Method}

The sampling frame of this survey is composed of all organizations published on the NASSCOM site on 14-Dec-2016, which are located in the Tricity (Chandigarh, Panchkula and Mohali) and NCR (New Delhi, Gurgaon and Noida) regions. The sampling frame of IT organizations reached 445 in number. A final sample size of 206 was achieved, assuming a 5\% confidence interval and a 95\% confidence level.

The survey questionnaire was forwarded to the 206 organizations and responses were received from 90 organizations with a response rate of more than $43 \%$; a value which by academic standards is quite acceptable; Kureshi et al., [66] and Brah et al,[67].

\subsection{Data Collection, Validation and Reliability Tests for Constructs}

The questionnaire was initially validated through a pilot study before it was finally used for primary data collection; 30 questions for measuring TQM constructs and 8 for getting information related to productivity levels in the pilot survey. 3 questions were removed as their removal improved the Chrobach alpha value of some constructs. Finally, 28 items were retained for the TQM constructs and 7 were retained for the productivity constructs.

Cronbach's alpha values, the standard of reliability for survey instruments, of all four Total Quality Management element constructs exceeded 0.70, which is considered acceptable as per Jung and Wang,[68] and George, D., and Mallery, P., [69]. Kline [70] indicated that a reliability coefficient with approximately 0.90 can be considered "excellent", values of around 0.80 as "very good," and values of around 0.70 as "adequate", depending on the survey.

The validity of the proposed model for measuring the theoretical constructs of TQM and productivity was further investigated through an exploratory factor analysis (EFA) technique. Below are a couple of observations recorded to validate the suitability of EFA in this study.

The correlations between TQM variables were calculated and many of them were greater than 0.3. Tabachnick \& Fidell [71] proposed that if most of the correlations 
are not in excess of 0.30 in the matrix, then factor analysis is inappropriate. $84 \%$ correlation values in the correlation matrix of 28 variables were significant at the 0.05 level, indicating sufficient correlations validating the application of factor analysis [72]. Fabrigar et al [73] suggested that the number of variables to be measured should be at least 3 to 5 times the number of expected common factors, and that these variables should consist of multiple other variables which are likely to be swayed by each of the common factors. Gorsuch [74] suggested that the ratio of participants to the measured variable should be 5 and that the sample size should not be less than 100 (for EFA). The adequacy of sample for suitability of applying EFA is measured through Kaiser-MeyerOlkin (KMO). The value of KMO, a measure of sampling adequacy, is 0.79 - a value in excess of the recommended 0.6 [75] - hence suitable for conducting EFA.

Thus, the preconditions for EFA as per the literature reviewed, were valid for this study. A cutoff point of 0.5 or more was used for Cronbach's alpha for the variable to be included in further EFA [67].

The Kaiser criterion (eigenvalue>1) was applied in combination with an assessment of scree plots as per Jung and Wang [68], to find the factors. Based on the same, 4 factors were considered for TQM including the one with avalue of 0.9, a little below 1 so as to suit the needs of the study. The four factors account for around 50 percent of the total variance of TQM.

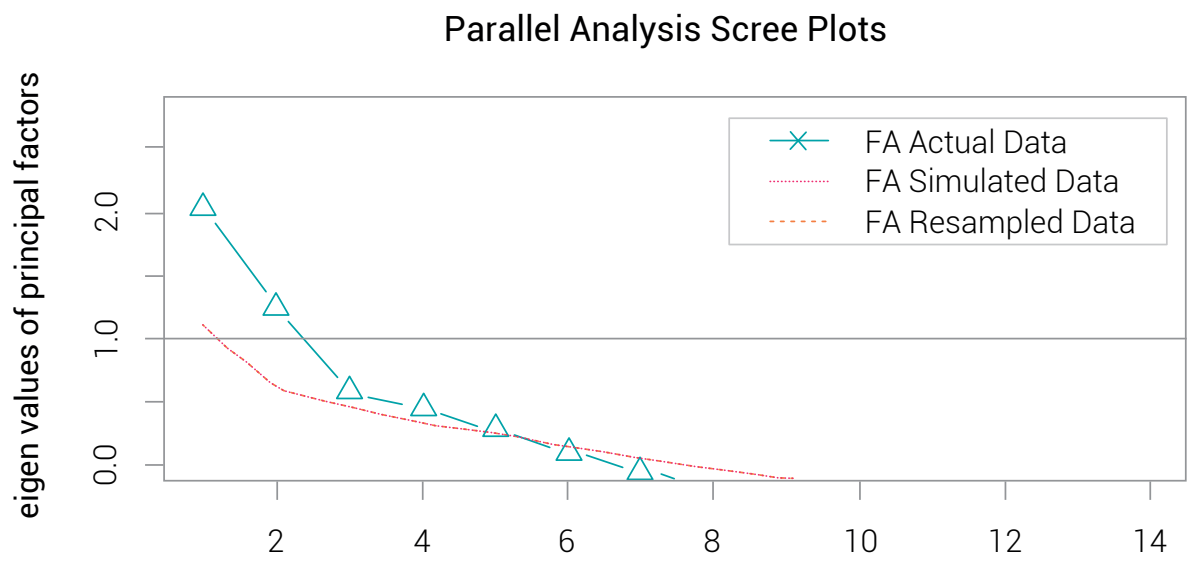

Factor Number

Figure 1. Scree Plot in R.

Source: own work 
Table1. Results of EFA and Alpha values for different Total Quality Management constructs.

\begin{tabular}{|c|c|c|}
\hline Factors & Variable Loadings & CronBach Alpha \\
\hline \multirow{4}{*}{ TMC } & 0.830 & \multirow{4}{*}{0.69} \\
\hline & 0.595 & \\
\hline & 0.715 & \\
\hline & 0.447 & \\
\hline \multirow{10}{*}{ PM } & 0.578 & \multirow{10}{*}{0.87} \\
\hline & 0.690 & \\
\hline & 0.487 & \\
\hline & 0.540 & \\
\hline & 0.824 & \\
\hline & 0.664 & \\
\hline & 0.563 & \\
\hline & 0.604 & \\
\hline & 0.528 & \\
\hline & 0.346 & \\
\hline \multirow{9}{*}{ CS } & 0.669 & \multirow{9}{*}{0.71} \\
\hline & 0.492 & \\
\hline & 0.722 & \\
\hline & 0.573 & \\
\hline & 0.604 & \\
\hline & 0.872 & \\
\hline & 0.706 & \\
\hline & 0.692 & \\
\hline & 0.812 & \\
\hline \multirow{5}{*}{$\mathrm{Cl}$} & 0.849 & \multirow{5}{*}{0.70} \\
\hline & 0.348 & \\
\hline & 0.767 & \\
\hline & 0.766 & \\
\hline & 0.717 & \\
\hline
\end{tabular}

Source: own work

A factor loading of 0.3 has been recommended by Nunnally [61], as a standard to define whether a variable is a part of a factor, but a value of 0.5 and above is considered as commendable [76], [67]. Hence, 0.3 was considered as a cut-off for acceptability of loadings for this study, but around $80 \%$ of the factor loadings were more than 0.5 . 
Table 2. Results of EFA and Alpha values for Productivity construct.

\begin{tabular}{ccc}
\hline Factors & Variable Loadings & CronBach Alpha \\
\hline & 0.586 & \\
\cline { 2 - 3 } & 0.684 & \\
\cline { 2 - 3 } & 0.707 & 0.65 \\
\hline \multirow{3}{*}{ PROD } & 0.539 & \\
\hline & 0.739 \\
\hline
\end{tabular}

Source: own work

The root mean square of the residuals (RMSR) came out to be 0.06 , which is fine as per Fuentes-Fuentes, [77], who considered RMSR $=0.10$ in their study on TQM principles and organization performance. The Tucker Lewis Index of factoring reliability was 0.9 and RMSEA index was 0.085. Both of them are acceptable and in line with Narasimhan, [78] and Fabrigar et al [73] respectively. RMSEA is defined as a measure of difference between the model and the data per degree of freedom for the model. It has been recommended that values less than 0.05 establish a good fit, while, between 0.05 to 0.8 range, it is considered as an acceptable fit. Values in range of 0.08 to 0.10 are considered to be a marginal fit and greater than 0.1 as a poor fit.

Results of the factor analysis indicate an acceptable level of construct validity of the measure. The same was true for the productivity construct where RMSR was 0.08, RMSEA was 0.7 and Tucker Lewis Index was 0.89.

As had been done in various studies like Abusa [51] and Petersen [32], stepwise linear regression was applied to analyze the relation between dependent variables i.e., productivity and independent TQM variables.

Multiple regression analysis is used to examine the relationship between the dependent variable productivity (PROD) and the four independent variables (TQM elements) which resulted from the factor analysis. The multiple regression method is an apt technique in examining the relationship between a single dependent variable and several independent variables with an aim of explaining the single dependent value defined using independent variables whose values are known [72].

The following assumptions for regression were validated prior to applying the step-wise method. 


\subsection{Correlation and Multicollinearity among TQM variables}

The correlation matrix showed that there is a significant correlation between all TQM and productivity constructs, as the $\mathrm{p}$-value for correlations was almost 0.

Table 3. Correlation matrix for TQM constructs (original)

\begin{tabular}{cccccc}
\hline Correlation & TMC & CUS & PM & CI & PROD \\
\hline TMC & 1 & 0.446093 & 0.654797 & 0.591118 & 0.55558 \\
\hline CUS & 0.446093 & 1 & 0.63549 & 0.451781 & 0.613052 \\
\hline PM & 0.654797 & 0.63549 & 1 & 0.742693 & 0.606957 \\
\hline CI & 0.591118 & 0.451781 & 0.742693 & 1 & 0.694984 \\
\hline PROD & 0.55558 & 0.613052 & 0.606957 & 0.694984 & 1 \\
\hline
\end{tabular}

VIF values were determined to check the levels of multicollinearity among TQM variables.

Table 4. VIF values for TQM constructs.

\begin{tabular}{cccc}
\hline TMC & CUS & PM & Cl \\
\hline 1.835795 & 1.686222 & 3.340864 & 2.336074 \\
\hline
\end{tabular}

Source: own work

Ekinci [79] in the study for quality criteria for hotels, stated that variables with VIF value below 3 can be considered for linear regression and above 3 can be removed from consideration for further analysis because of high correlation with other variables.

The PM variable was highly correlated with other variables and hence it was left for further regression analysis.

The values of the residuals are independent. This is principally the same as stating that we need the observations (or individual data points) to be independent from one another (or uncorrelated).

The same test as was performed by Ekinci [79], the Durbin-Watson test, was performed to check values providing the following results (in $\mathrm{R}$ ).

$$
D W=2.308, p \text {-value }=0.9034
$$




\section{Alternative hypothesis: true autocorrelation is greater than 0}

This indicated the null hypothesis of the test, which is; 'true autocorrelation is 0' can be accepted.

Verifying Heteroskedasticity: The presence of non-constant variance in the error terms results in heteroskedasticity. Generally, non-constant variance arises in presence of outliers or extreme leverage values.

The Residual-Fitted plot did not show any pattern and hence heteroskedasticity can be safely ignored.

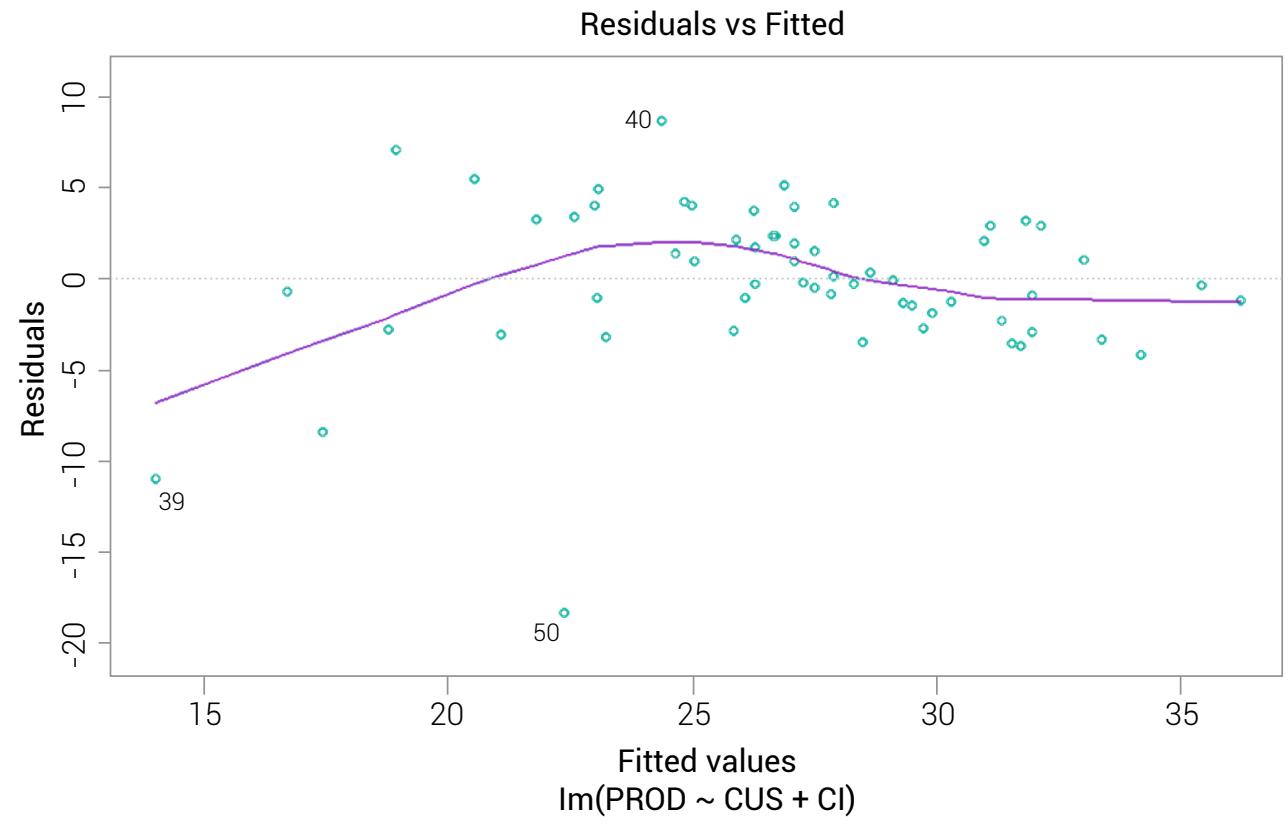

Figure 2. Residuals vs Fitted graph produced from a linear regression model performed on Productivity $\sim \mathrm{CUS}+\mathrm{Cl}$ in $\mathrm{R}$.

Source: own work

Normal Distribution of error terms was analyzed through a Normal Q-Q plot in R. Reviewing the graph confirmed normal distribution of error terms. 


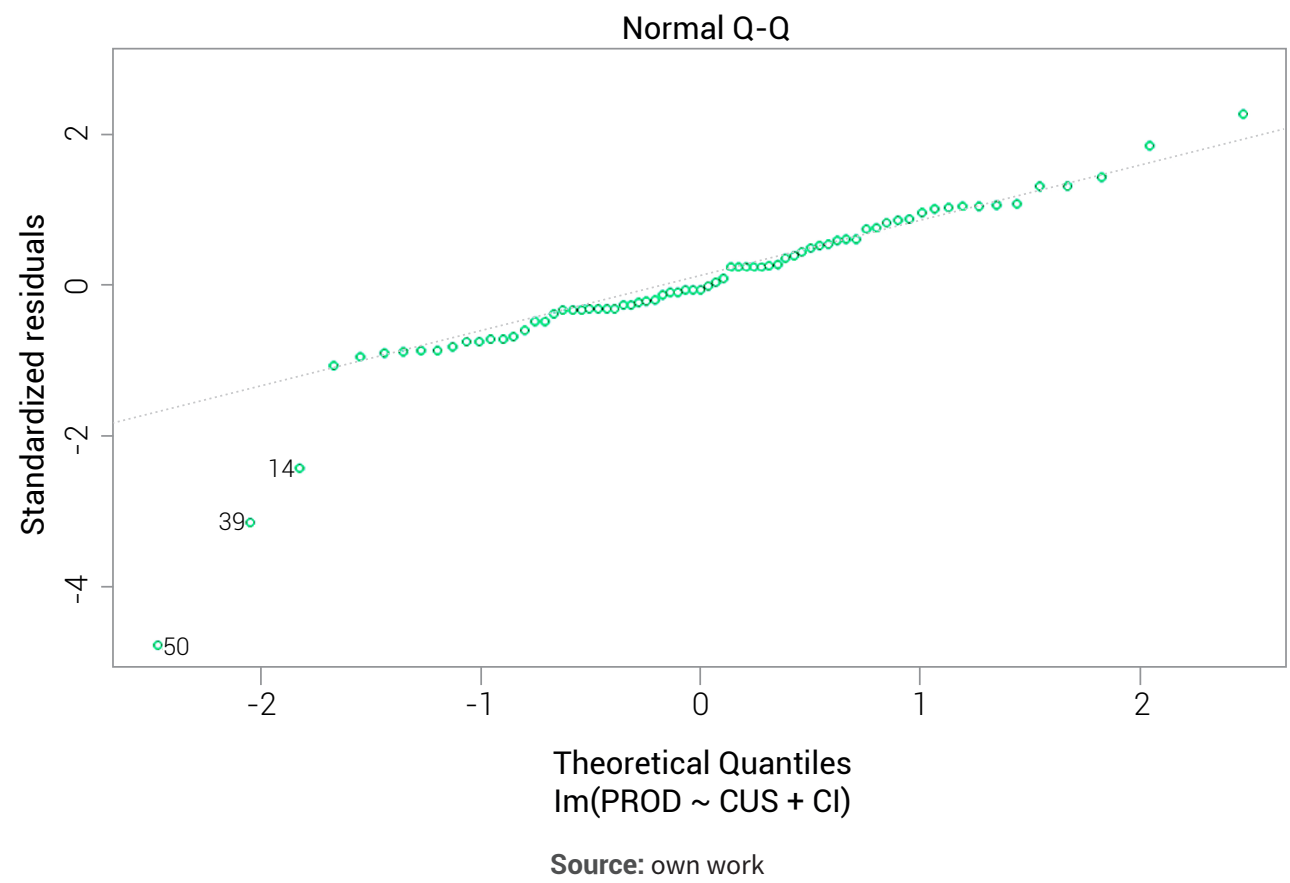

\section{Results of stepwise regression}

Residuals:

$\begin{array}{ccccc}\text { Min } & 1 Q & \text { Median } & 30 & \text { Max } \\ -18.3722 & -1.4852 & -0.2621 & 2.3600 & 8.6268\end{array}$

Table.5. Raw Linear Regression Model analysis output from R.

\begin{tabular}{ccccc}
\hline Coefficients: & Estimate & Std. Error & t value & $\operatorname{Pr}(>|\mathbf{t}|)$ \\
\hline (Intercept) & -9.37222 & 3.771 & -2.485 & $0.0153^{*}$ \\
\hline CUS & 0.40021 & 0.09076 & 4.409 & $3.67 \mathrm{e}-05^{\star \star \star}$ \\
\hline Cl & 1.02239 & 0.16589 & 6.163 & $4.03 \mathrm{e}-08^{* \star \star}$ \\
\hline
\end{tabular}

Source: own work

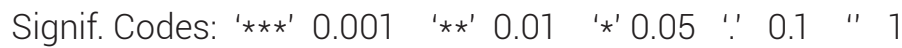

Residual standard error (Root mean squared error (RMSE)): 3.955 on 87 degrees of freedom

Multiple R-squared: 0.5954, Adjusted R-squared: 0.5838

F-statistic: 51.5 on 2 and 87 DF. The $p$-value is $<.00001$. The result is significant at $p<.05$ and hence the devised model is better than the intercept model. 


\section{RESULTS AND DISCUSSION}

The results show that the TQM independent variables 'Continuous Improvement' and Customer Focus have the greatest influence towards achieving productivity (dependent variable) with a beta coefficient of 1.02239 and 0.40021 respectively, and together explain around 58.5 percent of the variance of the dependent variable. The p-value for $\mathrm{F}$ statistic is significant at 0.05 alpha levels and confirms that the model, arrived at in this study, is better than the intercept model (all regression coefficients 0 ). The results from stepwise regression also reveal that 'TMC; does not have a significant impact on the dependent (productivity) variable.

Following hypotheses were formed, initially.

1. Ho: TMC does not have any significant impact on productivity.

2. Ho: PM does not have any significant impact on productivity.

3. Ho: CF does not have any significant impact on productivity.

4. Ho: $\mathrm{Cl}$ does not have any significant impact on productivity.

It is concluded from the analysis above that Null Hypotheses 3 and 4 can be rejected in favor of alternate hypotheses but null hypothesis 1 cannot be rejected. We already analyzed and left PM from the list of independent variables because of its high correlation with other independent variables. It may seem odd that the TMC variable was not found to be significant in terms of its impact on productivity, but it should also be noted that TMC also had a correlation with CF and CI. Hence, the indirect impact of TMC on productivity may not be ignored in its totality.

\section{CONCLUSION}

\subsection{Findings and Suggestions}

This study investigated the relation between four TQM constructs and a productivity construct. It was inferred that Customer Focus and Continuous Improvement are positively and significantly related to productivity while Total Management Commitment was not so significant in terms of impact on productivity.

- Senior management in software development organizations can focus on customer needs and continuous improvement which may indirectly improve productivity. 


\subsection{Scope for further study}

- There are several other elements (soft and hard) of TQM which may be studied and analyzed for their relation to productivity. Based on available resources, a larger region could be studied and analyzed for a similar study. Productivity measurement concept has a lot of variation in terms of what factors should be included to measure the productivity. This may also depend upon the type and culture of the organization. Different factors impacting the productivity can be considered while collecting the information through a survey.

\section{REFERENCES}

[1] Mishra, Alok, A. Yazici, and S. Cetin, "Software evolution in Turkey," Tehnički vjesnik, vol. 23, no. 3, pp. 43-46 929-935. [Online]. doi:10.2991/jnmp.2006.13.4.1

[2] J. P. Singh, N. Kumar, and S. Uzma, "Satyam Fiasco: Corporate Governance Failure and Lessons Therefrom," IUP Journal of Corporate Governance, vol, 9, no. 4, pp. 54-64; 130-230. [Online]. doi: 10.1037/arc0000014

[3] Deming, W. Edwards, Out of the Crisis. MIT press, 2018. pp. 34-54. [Online]. doi: 10.1111/ bjet.12103

[4] M. Asher and G. Kanji (1996). 100 Methods for Total Quality Management. Sage Publications. [Online]. doi: 10.0101/bjet.12104

[5] B. Kitchenham and E. Mendes, "Software productivity measurement using multiple size measures," IEEE Trans. Softw. Eng., vol. 30, no. 12, pp. 1023-1035, 2004. [Online]. doi: 10.57746/ bjet.12103

[6] Nasir, Hassan, et al., "An integrated productivity-practices implementation index for planning the execution of infrastructure projects," Journal of Infrastructure Systems, vol. 22, no. 2, pp. 74-93. [Online]. doi: 10.04015/022.

[7] K. Kassicieh and S. Yourstone, "Training, Performance evaluation, rewards and TQM Implementation Success,” J. Qual. Manag., vol. 3, no. 1, pp. 25-38, 1998. [Online]. doi: 10.8478/ bjet.18503 
[8] S. Rahman and P. Bullock, "Soft TQM, hard TQM, and organisational performance relationship: An empirical investigation,” Omega, vol. 33, pp. 73-83, 2005. [Online]. doi: 10.1758/ bjet. 12758

[9] Y. Choong, "Perception and development of total quality management in small manufacturers: An exploratory study in China," . J. Small Bus. Manag., vol. 42, no. 1, pp. 102-115, 2018. [Online]. doi: 10.8473/bjet.84778

[10] D. Samson and M. Terziovski, "The relationship between total quality management practices and operational performanc," J. Oper. Manag., vol. 17, no. 4, pp. 393-409, 1999. [Online]. doi: 10.3564/bjet.56478

[11] J. Dean and D. Bowden, "Management theory and total quality: Improving research and practice through theory development," Acad. Manag. Rev., vol. 19, no. 3, pp. 392-418, 1994. [Online]. doi: 10.5465/bjet.18503

[12] J. Haar and C. Spell, "Total quality management; Organizational structures; New Zealand,” J. Enterp. Inf. Manag., vol. 21, no. 2, pp. 162-178, 2008. [Online]. doi: https://doi. org/10.1108/17410390810851408

[13] S. Brah, S. Tee, and B. Rao, "Relationship between TQM and Performance of Singapore Companies. TQMand business performanceintheservicesector:ASingaporestudy," Int. J. Qual. Reliab.Manag.,vol.19, no.4, pp.356-379,2002. [Online]. doi:doi/10.1108/02656710210421553

[14] A. Oluwatoyin and A. Oluseun, "Total Quality Management. A Test of the Effect of TQM on Performance and Stakeholder Satisfaction," Unpubl. Master thesis, Sch. Manag. Blekinge Inst. Technol., pp 34-543, 2009. [Online]. doi: 10.5888/bjet. 833631

[15] P. Corredor and S. Goñi, "TQM and performance: Is the relationship so obvious?," J. Bus. Res., vol. 64, no. 8, pp. 830-838, 2011. [Online]. doi: 10.4546/bjet. 756631

[16] D. Hoanga, B. Igelb, and T. Laosirihongthongc, "Total quality management (TQM) strategy and organizational characteristics: Evidence from a recent WTO member," Total Qual. Manag., vol. 21, no. 9, pp. 931-951, 2010. [Online]. doi: 10.0390/bjet. 354672

[17] M. Krishnan, C. Kriebel, S. Kekre, and T. Mukhopadhyay, "An Empirical Analysis of productivity and Quality in Software Products," Manage. Sci., vol. 46, no. 6, pp. 745-759, 2000. [Online]. doi: doi/abs/10.1287/mnsc.46.6.745.11941 
[18] N. Slack, S. Chambers, and R. Jonhston, Operations Management, Third. Harlow: Prentice Hall, pp. 24-34, 2001. [Online]. doi: doi/abs/10.3256/mnsc.46.6.745.11941

[19] R. Schroeder, Operations Management: Decision Making in the Organisations Function. New York: McGraw-Hill, p. 34, 1985. [Online]. doi: 10.8674/.46.6.745.11941

[20] E. Sasser, D. Wyckoff, and M. Olsen, The Management of Service Operations. New York: Allyn and Bacon, pp 34-64, 1978. [Online]. doi: 10.8674/.46.6.745.11941

[21] C. Witt and S. Witt, "Why productivity in the Hotel Sector is Low," Int. J. Contemp. Hosp. Manag., vol. 1, no. 2, pp. 28-33, 1989. [Online]. doi: /abs/10.1108/EUM0000000001669

[22] P. Jones, "Quality, capacity and productivity in service industries," Int. J. Hosp. Manag., vol. 7, no. 2, pp. 104-112, 1988. [Online]. doi: 10.0278/EUM0000000001669

[25] G. Low and D. Jeffrey, "Function Points in the Estimation and Evaluation of the Software Process," IEEE Trans. Softw. Eng., vol. 16, no. 1, pp. 64-71, 1990. [Online]. doi: abs/10.6758/ M0000000001

[26] R. Banker and R. Kauffman, "Reuse and productivity in Integrated Computer-Aided Software Engineering: An Empirical Study," MIS Q., vol. 15, no. 3, pp. 375, 1991. [Online]. doi: 2451/14331/1/IS-92-152451/14331/1/IS-92-15

[27] J. Capers, "Positive and negative innovations in software engineering," International Journal of Software Science and Computational Intelligence (IJSSCI), vol. 1, no. 2, pp.20-30, 2009. [Online]. doi: 10.016295d

[28] A. Albrecht and J. Gaffney, "Software Function, Source Lines of Code, and Development Effort Prediction: Software Science Validation,” IEEE Trans. Softw. Eng., vol. 9, no. 6, pp. 639-647, 1983. [Online]. doi: 10.8674/.46.6.745.11941

[29] J. Sprouls, IFPUG Function Point Counting Practices Manual, 1990. [Online]. doi: 10.8674/.46.6.745.11941

[30] C. Symons, "Function Point Analysis: Difficulties and Improvements," IEEE Trans. Softw. Eng., vol. 14, no. 1, pp. 2-10, 1988. [Online]. doi: 10.0434/.46.6.745.75641

[31] R. Banker, S. Datar, and C. Kemerer, "A Model to Evaluate Variables Impacting the productivity of Software Maintenance Projects," Manage. Sci., vol. 37, no. 1, pp. 1-18, 1991. [Online]. doi: 10.3664/.46.6.843.11941 
[32] K. Petersen, "Measuring and predicting software productivity: A systematic map and review," Inf. Softw. Technol., vol. 53, no. 4, pp. 317-343, 2011. [Online]. doi: 10.0023/.46.6.745.95493

[33] S. D. Conte,H.E. Dunsmore, and Y.E. Shen, Softwareengineering metrics and models. BenjaminCummings Publishing Co., Inc., pp 13-56, 1986. [Online]. doi: 10.7584/.46.86745.11941

[34] A. Lowell Jay. Measuring programmer productivity and software quality, John Wiley \& Sons, Inc., 1985 pp 23. [Online]. doi: 10.9449/.46.664831941

[35] B. W. Boehm, Software engineering economics, vol. 197. Englewood Cliffs (NJ): Prentice-hall, pp 24-25 1981. [Online]. doi: 10.2002/.4978.745.11941

[36] L. H. Putnam, "Linking the QSM productivity index with the SEI maturity level," 2000, no. 7, pp. 43, 2000. [Online]. doi: 10.1.1.519.8013

[37] C. E. Walston, and Ch. P. Felix, "A method of programming measurement and estimation," IBM Systems Journal, vol. 16, no. 1, pp. 54-73, 1977. [Online]. doi: 10.4758. 9.8013

[38] J. W. Bailey and V. R. Basili, "A meta-model for software development resource expenditures," Proceedings of the 5th international conference on Software engineering, pp. 107-116. 1981. [Online]. doi: 10.4502/.49564.745.11941

[39] J. Vosburgh, B. Curtis, H. Krasner, and N. Iscoe, "A field study of the software design process for large systems," Communications of the ACM , vol. 31, pp. 11, 1988. [Online]. Available: http:// www2.unifap.br/furtado/files/2015/03/Artigo-3.pdf

[40] J. D. Aron, "Estimating resources tor large programming systems," Software Engineering: Concepts and Techniques, JM Buxton, et al. Eds, 1976. pp. 206-217. [Online]. doi: $10.6574 / .8593 .745 .11941$

[41] B. A. Kitchenham, "Empirical studies of assumptions that underlie software cost-estimation models," Inf. Softw. Technol., vol. 34, no. 4, pp. 211-218, 1992. [Online]. doi: 10.8587/.8578.748.45.11941

[42] Brooks and W. Douglas, "Software Technology Payoff: Some Statistical Evidence," J. Syst. Softw., vol. 2, pp. 3-9, 1981. [Online]. doi: 10.0948/.64783.745.11941

[43] C. Jones, Applied Software Measurement: Assuring productivity and Quality. New York: McGraw-Hill, pp. 4-23, 1991. [Online]. doi: 0.2756/240816084 
[44] K. Maxwell and For, "Benchmarking software development productivity," IEEE Softw., vol. 17, no. 1, pp. 80-88, 2000. [Online]. doi: 10.1.876.4955

[45] A. Trendowicz and J. Munch, "Factors inuencing software development productivity (stateof-the-art and industrial experiences)," Adv. Comput., vol. 77, pp. 185, 2009. [Online]. doi: $=; 1.1 .718 .4955$

[46] J. Khan, "Impact of total quality management on productivity," TQM Mag., vol. 15, no. 6, pp. 374-380, 2003. [Online]. doi: 10.5643/97584-3-319-27799-8_16

[47] J. D. Blackburn, D. G. Scudder, and L. N. Van Wassenhove, "Improving speed and productivity of software development: a global survey of software developers," IEEE transactions on software engineering, vol. 22, no. 12, pp 875-885, 1996. [Online]. doi: 10.7463/978-3-319-27799-8_16

[48] O. Giarini, Liyanage, and P. Jayantha, "Perspectives on Performance Assessment and Management," Value Networks in Manufacturing, pp. 273, 2017. [Online]. doi: 10.1007/978 -3-319-27799-8_16

[49] C. Grönroos, "Scandinavian management and the Nordic school of services-contributions to service management and quality," International Journal of Service Industry Management, vol. 2, no. 3, pp17-26, 1991. [Online]. doi: 10.4748/3837-3-319-27799-8_16

[50] D. Anselmo and H. Ledgard, "Measuring productivity in the software industry," Commun. ACM, vol. 46, no. 11, pp. 121-125, 2003. [Online]. doi: 10.4675/978-3-319-27799-8_16

[51] F. Abusa, Jaiswal, Kapil, and Minakshi Garg, "Tqm Implementation and Organizational Characteristics: A Study on Tri-City Region." Gurukul Business Review-GbR, vol. 14, pp. 52-61, 2018. [Online]. doi: 10.4654/978-3-0494-9484-8_16

[52] L. Bani Ismail, An evaluation of the implementation of Total Quality Management (TQM) within the construction sector in the United Kingdom and Jordan. Diss. University of Huddersfield, pp 13-23, 2012. [Online]. doi:10.14055/1/0666332

[53] Gharakhani, Davood, et al., "Total quality management and organizational performance," American Journal of Industrial Engineering, vol. 1, no. 3, pp. 46-50, 2013. [Online]. doi: $10.4055 / 1 / 0666332$

[54] J. Ali Bakhit and Z. Abedalfattah Al-abedallat, "The effect of quality management practices on organizational performance in Jordan: An empirical study," International Journal of Financial Research, vol. 4, no. 1, pp 93-109, 2013. [Online]. doi: 10.6574/.8593.745.11941 
[55] D. I. Prajogo and S. Amrik Sohal, "The relationship between organization strategy, total quality management (TQM), and organization performance--the mediating role of TQM," European journal of operational research, vol. 168, no.1, pp. 35-50, 2006. [Online]. doi: 10.8495/8593.745.11941

[56] H. Kaynak, "The relationship between total quality management practices and their effects on firm performance," Journal of operations management, vol. 21, no. 4, pp. 405-435, 2003. [Online]. doi: 10.4573/.853.745.11941

[57] J. C. Anderson, M. Rungtusanatham, and R. G. Schroeder, "A theory of quality management underlying the Deming management method," Academy of management Review, vol. 19, no. 3, pp. 472-509, 1994. [Online]. doi: 10.0904/.88578.745.11941

[58] Forza, Cipriano, and R. Filippini, "TQM impact on quality conformance and customer satisfaction: a causal model," International journal of production economics, vol. 55, no. 1, pp. 1-20, 1998. [Online]. doi: 10.7748/.4088.745.11941

[59] Ahire, L. Sanjay, and P. Dreyfus, "The impact of design management and process management on quality: an empirical investigation," Journal of operations management, vol 18, no. 5, pp. 549-575, 2000. [Online]. doi: 10.0950/.85785.5.11941

[60] B. Flynn, R. Schroeder, and S. Sakakibara, "The impact of quality management practices on performance and competitive advantage,” Decis. Sci., vol. 26, pp. 659-691, 1995. [Online]. doi: https://doi.org/10.1111/j.1540-5915.1995.tb01445.x

[61] J. C. Nunnally, Psychometric Theory, 2d Ed. McGraw-Hill, p. 23, 1978. [Online]. doi: 10.7584/.95894.745.11941

[62] F. Talib, Z. Rahman, and M. N. Qureshi, "An empirical study of barriers to TQM implementation in Indian service industries," Proceedings of First International Conference on Industrial Engineering (ICIE 2011), organized by Department of Mechanical Engineering, SV National Institute of Tech. 2011. [Online]. doi: 10.4844/.85949943.745.11941

[63] Kumar, Raj, Dixit Garg, and T. K. Garg, "TQM success factors in North Indian manufacturing and service industries," The TQM Journal, vol. 23, no.1, pp. 36-46, 2011. [Online]. doi: $10.0003 / .8593 .968 .11941$

[64] I. Salaheldin, Salaheldin, "Critical success factors for TQM implementation and their impact on performance of SMEs," International journal of productivity and performance management, vol. 58, no. 3, pp. 215-237, 2009. [Online]. doi: 10.6574/.8593.745.11941 
[65] E. Attakora-Amaniampong, A. Salakpi, and F. Bonye, "Total Quality Management and its Impact on the Level of CUStomer FoCUS within Construction Project Management in Ghana," Int. J. Bus. Manag. Invent., vol. 3, no. 7, pp. 36-48, 2014. [Online]. doi: 10.7584/.8944.745.89443

[66] Kureshi, Nadeem, F. Qureshi, and A. Sajid, "Current health of quality management practices in service sector SME- a case study of Pakistan," TQM J., vol. 22, no. 3, pp. 317-329, 2010. [Online]. doi: 10.0909/.8593.745.11941

[67] Brah, A. Shaukat, J. L. Wong, and B. Madhu Rao, "TQM and business performance in the service sector: A Singapore study," Int. J. Oper. Prod. Manag., vol. 20, pp. 1293-1312, 2000. [Online]. doi: 10.7843/.74673.745.11941

[68] Y. Jung, Joo and Yo Jian Wang, "Relationship between total quality management (TQM) and continuous improvement of international project management (CIIPM)," Technovation, vol. 26, pp. 716-722, 2006. [Online]. doi: 10.1001/.8593.745.11941

[69] G. Darren and P. Mallery, SPSS for Windows step by step: A simple guide and reference, Fourth. Boston: Allyn and Bacon, pp. 45-84, 2003. [Online]. doi: 10.2100/.8593.745.11941

[70] R. Kline, Principles and Practice of Structural Equation Modeling. New York: Guildford Press, pp. 32-76, 1998. [Online]. doi: 10. 2753/.8593.745.11941

[71] B. G. Tabachnick, L. S. Fidell, and J. B. Ullman, Using multivariate statistics, vol. 5. Boston, MA: Pearson, pp. 223-321, 2007. [Online]. doi:10. 0134.790545

[72] J. Hair, R. Anderson, R. Tatham, and W. Black, Multivariate data analysis. Upper Saddle River: Prentice Hall, pp. 54-74, 1998. [Online]. doi: 10. 8765.7905.45

[73] L. Fabrigar, D. Wegener, R. Maccallum, and E. Strahan, "Evaluating the use of exploratory factor analysis in psychological research," Psychol. Methods, vol. 4, no. 3, pp. 272-299, 1999. [Online]. doi: 10. 1134.790545

[74] R. L. Gorsuch and S. E. McPherson, "Intrinsic/extrinsic measurement: I/E-revised and single-item scales," Journal for the Scientific study of Religion, pp. 348-354, 1998. [Online]. Available: https://www.researchgate.net/profile/Joshua_Wright8/post/How_can_I_get_ access_to_the_Revised_Intrinsic_Extrinsic_Religious_Orientation_Scale/attachment/5a5d80ea4cde266d588355ae/AS:583284585648128@1516077290258/download/ Gorsuch+\%26+McPherson+Revised+1\%3AE+Scale.pdf 
[75] H. F. Kaiser, "An index of factorial simplicity," Psychometrika, vol. 39, no. 1, pp. 31-36, 1974. [Online]. doi: 10.0134.790545.

[76] B. A. Shaukatand and H. Y. Lim, "The effects of technology and TQM on the performance of logistics companies," International Journal of Physical Distribution \& Logistics Management, vol. 36, no. 3, pp. 192-209, 2006. [Online]. doi: 10. 9134.790945.

[77] M. M. Fuentes-Fuentes, C. A. Albacete-Sáez, and F. J. Lloréns-Montes, "The impact of environmental characteristics on TQM principles and organizational performance," Omega, vol. 32, no. 6, pp. 425-442, 2004. [Online]. doi: 10. 0134.354.790545.

[78] S. Narasimhan, "A study on effective implementation of tqm for sustainability," pp. 45, 2014. [Online]. doi: 10. 10603/42995/5/05

[79] E. Yuksel, An examination of generic service quality criteria for the evaluation of hotels. Diss: University of Surrey, pp. 64, 1999. [Online]. doi:10. 2980.66/42995/5/05 